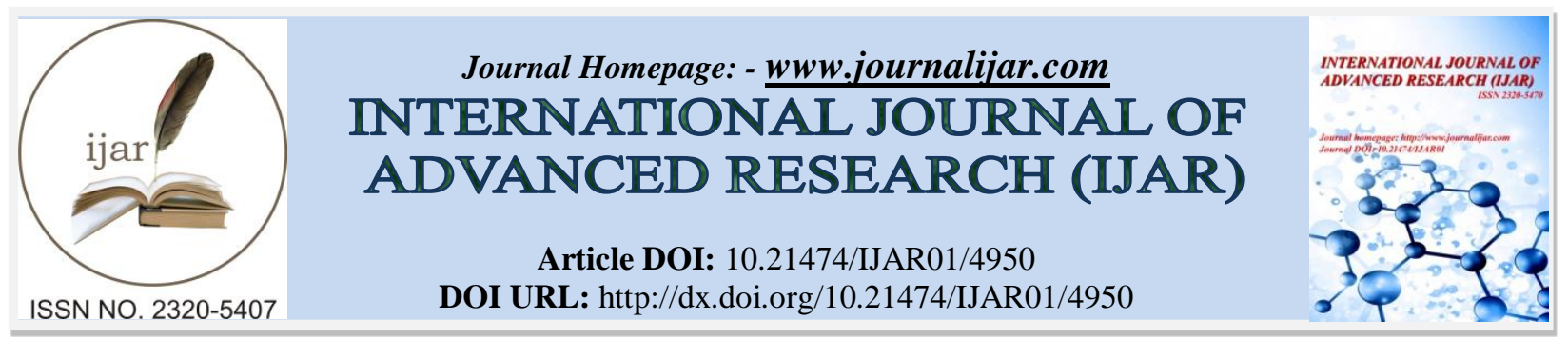

RESEARCH ARTICLE

\title{
SOCIO-ECONOMIC PROFILE OF PRI'S BELONGS TO SCHEDULED CASTES: A SOCIOLOGICAL STUDY OF RURAL HARYANA.
}

Subhash Sinhmar.

Research Scholar, Department of Sociology, K.U.Kurukshetra, Haryana.

\section{Manuscript Info}

\section{Manuscript History}

Received: 25 May 2017

Final Accepted: 27 June 2017

Published: July 2017

Key words:-

Socio-Economic, Occupation,

Agriculture, Houses, Goddess.

\section{Abstract}

The present study was carried out to know the socio-economic profile of Scheduled Castes PRI's members in rural area of Haryana. With the help of stratified random sampling method 572 respondents (409 Panches, 69 Sarpanches, 72 Block Samities Members and 22 Zila Parishad Members were selected from the universe of the study. All the respondents are PRI's elected members, belongs to nine castes (Chamar, Ravidasiya Sikh, Majhabi Sikh, Balmiki, Dhanak, Odd, Sainsi, Bazigar, Kabir Panthi) of SC's. Chamar out of nine castes have high percentage of elected members as panch $(35.3 \%)$, Sarpanch (5.4\%), Block Samities (6.3\%) and Zila Parishad (2.4\%) in PRI's. In age group 40 to 49 years the respondents belong to the Chamar (13.5\%), Balmiki (4.4\%), Dhanak (1.9\%), Ramdasiya Sikh (1.7\%), Sainsi $(1.6 \%)$ are in maximum numbers and Kabir Panthi $(.7 \%)$ and Odd $(.3 \%)$ are in minimum numbers. Chamar $(2.1 \%)$ are highly UG passed and Odd (.3\%), Ramdasiya Sikh, Balmiki (.2\%) each are numerically low UG passed. Chamar (1.2\%), Majhabi Sikh and Kabir Panthi (.2\%) each having 8 to above agriculture land. Chamar (33.9\%), Balmiki (14.3\%), Ramdasiya Sikh ( 6.8\%), Dhanak (4.7\%), Sainsi (3.7\%), and Kabir Panthi (.9\%) have no agriculture land. No one have from the Caste Odd $(.0 \%)$ having income up to 60000rs. In the income group 4 lakh and above, Chamar (2.4\%) are the maximum and Dhanak, Kabir Panthi $(.0 \%)$ each have no percentage in this group. Majority of the respondents i.e. approximately $50 \%$ were lived in Pakka house with separate toilet, bathroom and RCC roof in each castes from the selected sample. Chamar (1.6\%) have TV, Freeze, Car, Bike, Ac in maximum numbers and Kabir Panthi have .2\% minimum numbers. Ramdasiya Sikh, Majhabi Sikh, and Kabir Panthi have no one such these goodies in their home.

Copy Right, IJAR, 2017,. All rights reserved.

\section{Introduction:-}

The Scheduled Castes (SCs), unlike the Scheduled Tribes (STs), to live along with the rest of the population in the village the wider part of the country. They constitute an important subsystem of the rural production system.

The suffering of the Scheduled Caste varies from region to caste in the time frame. Those people who belongs to Scheduled Castes have been considered as disabled masses. Their disabilities could be in the nation of economic, 
educational, social, political, and psychological or a combination of several of these factors. A rough estimate indicates that there are 3000 castes in the country out of which 779 are Scheduled Castes. Besides these, 779 castes are divided further into different sub castes (Singh, 1995).

The institutionalised inequality in the caste system manifests its extreme form in growth of completely segregated set of castes called 'untouchable castes'. The Scheduled Castes (SCs) who comprise the bulk of untouchable are technically outside the four fold Varna scheme. These castes were imputed with maximum degree of ritual and social impurity, while their occupations were held to be the lowest in normative hierarchy. This led to their residential segregation in village and town (Ahuja, 2005).

In most villages, they continue to suffer residential segregation and, derive their sustenance from agriculture Those who have changed their traditional occupations face less status disabilities. In some cases, however, the suffering is because of hereditary identity (Sachidannada, 1977). Yet they have not succeeded in transforming the larger system so that its process could be used in effective social, economic and political equality (Lal, 1999).

Politically, Dalits are becoming conscious of the fact they have to take advantage of their vast numbers in political terms. They may not be united to form many political parties but by supporting the dominant national political parties like Congress or Janta Dal or BSP. etc., they extract the price of their support. But the problem is that though the educated Dalits show evidence of politicization, the masses are not very much touched by this process. The elite have moved from the politics of compliance, affirmative pressure and protest but they are still not able to present a common front and adopt a radical posture (Ahuja, 2005).

Increasing economic stratification within caste affects political preference, behaviour, and the unity of caste members on political issues. The dominant stratum of the caste often projects while bargaining with the government. For instance, the elites of the SCs and OBCs emphasize reservation in government jobs, higher educational facilities, and more berths in the state cabinet and other public institutions rather than the implementation of land reforms, the distribution of land, and higher wages for labours- issues which affect most members of the caste. At the same time, while bargaining with the authorities, they do talk about poverty and deprivation. They use ethnic symbols and idioms to seek the backing of large numbers of cast fellows. Economic differentiation has led to tension within deprived castes. Though, they look towards the educated and relatively well-placed members of their castes for help. The poor complain that the latter corner benefits provided by the government. In some regions they have begun to assert themselves against the elites of their castes (Shah, 2002).

\section{Panchayati Raj in Haryana State:-}

The failure of community developed programme (1952) has led to appointment Balwant Rai Mehta committee (1956) which stress the need of 'democratic decentralization' through three tier system of Panchayati Raj at village, block and district level. This system of popular bodies has been developed to ensure people's participation in the development process. Actually, Panchayati Raj apparatus is still being considered as the volatile of development and socio-political transformation of rural sector (Malik, 2005).

The institution if Gram Panchayat was setup in Punjab state as per the provisions of Punjab Gram Panchayat Act 1952, on mandatory basis. This act was amended in 1960, and when Haryana became a separate state in 1966, the PRI's, were having three structure. These included the Gram Panchayat (under the amended act), the Panchayat Samities and Zila Parishad established as per the provisions of amended form of Punjab Gram Panchayat Act, 1961, Punjab Panchayat Samities and Zila Parishad Act 1961 respectively. Since the creation of Haryana in 1966 till 1993 the Punjab Gram Panchayat Act, 1961 was amended nineteen times and amendment made in Haryana act of 1987, made provision for reservation of seat for the members of Backward castes if their population was two percent or more in gram sabha area. It also provided for representation of one member of the backward classes in the Panchayat Samities. The past 73rd constitutional amendment which in turn resulted in the enactment of new Haryana Panchayati Raj Act 1994 and subsequent amendment is this act have not only restored three tier structure of Panchayati Raj in the state but also provided for reservation of seats for women, SC's, backward classes in all the three levels of these institution (Malik, 2012).

Methodology, sample procedure and technique of data Collection:-

This study will try to know socio-economic profile PRI's among the scheduled castes in rural areas of Haryana. To understand socio-economic profile among the scheduled castes PRI's information regarding their personal (age \& 
sex) and social background variable such as occupation, income, caste, religion, education, residence etc. needs to be collected. Hence, this study follows exploratory-cum- descriptive research design.

\section{Area of the study:-}

The field work is conducted in the state of rural Haryana. As a whole it is difficult to work on all over Haryana to know the socio-economic profile among the scheduled castes activists. Present study is limited in its scope; it is limited to only PRI's rural peoples who are including in scheduled castes in Haryana. As per reservation policy in parliament, in Haryana there is two reserved seats for the scheduled castes which are the Sirsa and Ambala.

Table. No. 1:- Distribution of SC members in Panchayats, Panchayat Samities and Zila Parishad

\begin{tabular}{|c|c|c|c|c|c|c|c|c|c|}
\hline \multirow[t]{2}{*}{ Constituency } & \multirow[t]{2}{*}{ District } & \multicolumn{4}{|c|}{ Panchayat } & \multirow{2}{*}{\multicolumn{2}{|c|}{$\begin{array}{l}\text { Panchayat } \\
\text { Samiti }\end{array}$}} & \multirow{2}{*}{\multicolumn{2}{|c|}{$\begin{array}{l}\text { Zila } \\
\text { Parishad }\end{array}$}} \\
\hline & & \multicolumn{2}{|c|}{ Panches } & \multicolumn{2}{|c|}{ Sarpanches } & & & & \\
\hline \multirow{4}{*}{ Ambala } & \multirow{2}{*}{$\begin{array}{l}\text { Ambala } \\
\text { (Ambala City, } \\
\text { Cantt, } \\
\text { Mullana) }\end{array}$} & $\mathrm{M}$ & $\mathrm{F}$ & $\mathrm{M}$ & $\mathrm{F}$ & $\mathrm{M}$ & $\mathrm{F}$ & $\mathrm{M}$ & $\mathrm{F}$ \\
\hline & & $\begin{array}{l}567 \\
10 \% \\
56.7 \\
\mathbf{5 6} \\
\end{array}$ & $\begin{array}{l}504 \\
10 \% \\
50.4 \\
\mathbf{5 0} \\
\end{array}$ & $\begin{array}{l}65 \\
20 \% \\
13.0 \\
\mathbf{1 3} \\
\end{array}$ & $\begin{array}{l}46 \\
20 \% \\
9.2 \\
9 \\
\end{array}$ & $\begin{array}{l}24 \\
40 \% \\
9.6 \\
9 \\
\end{array}$ & $\begin{array}{l}18 \\
40 \% \\
7.2 \\
7 \\
\end{array}$ & $\begin{array}{l}4 \\
80 \% \\
3.2 \\
3 \\
\end{array}$ & $\begin{array}{l}4 \\
80 \% \\
3.2 \\
\mathbf{3} \\
\end{array}$ \\
\hline & $\begin{array}{l}\text { Panchkula } \\
\text { (Pkl, Kalka, } \\
\text { Barwala) }\end{array}$ & $\begin{array}{l}78 \\
10 \% \\
7.8 \\
\mathbf{8} \\
\end{array}$ & $\begin{array}{l}104 \\
10 \% \\
10.4 \\
\mathbf{1 0} \\
\end{array}$ & $\begin{array}{l}15 \\
20 \% \\
3.0 \\
\mathbf{3} \\
\end{array}$ & $\begin{array}{l}10 \\
20 \% \\
2.0 \\
\mathbf{2} \\
\end{array}$ & $\begin{array}{l}4 \\
40 \% \\
1.6 \\
2 \\
\end{array}$ & $\begin{array}{l}5 \\
40 \% \\
2.0 \\
2 \\
\end{array}$ & $\begin{array}{l}1 \\
80 \% \\
.80 \\
1 \\
\end{array}$ & $\begin{array}{l}1 \\
80 \% \\
.80 \\
1 \\
\end{array}$ \\
\hline & $\begin{array}{l}\text { Yamuna Nagar } \\
\text { (Bilaspur } \\
\text { Sadhora, } \\
\text { Chachroli) }\end{array}$ & $\begin{array}{l}504 \\
10 \% \\
50.4 \\
50\end{array}$ & $\begin{array}{l}437 \\
10 \% \\
43.7 \\
44\end{array}$ & $\begin{array}{l}58 \\
20 \% \\
11.6 \\
\mathbf{1 2}\end{array}$ & $\begin{array}{l}24 \\
20 \% \\
4.8 \\
5\end{array}$ & $\begin{array}{l}16 \\
40 \% \\
6.4 \\
6\end{array}$ & $\begin{array}{l}15 \\
40 \% \\
6.0 \\
6\end{array}$ & $\begin{array}{l}3 \\
80 \% \\
2.40 \\
2\end{array}$ & $\begin{array}{l}2 \\
80 \% \\
1.60 \\
2\end{array}$ \\
\hline \multirow{7}{*}{ Sirsa } & $\begin{array}{l}\text { Sirsa } \\
\text { (Elnabad, } \\
\text { Kalawali, } \\
\text { Dabwali, } \\
\text { Sirsa, Raniya }\end{array}$ & $\begin{array}{l}537 \\
10 \% \\
53.7 \\
\mathbf{5 4}\end{array}$ & $\begin{array}{l}450 \\
10 \% \\
45.0 \\
\mathbf{4 5}\end{array}$ & $\begin{array}{l}42 \\
20 \% \\
8.40 \\
\mathbf{8}\end{array}$ & $\begin{array}{l}23 \\
20 \% \\
4.60 \\
5\end{array}$ & $\begin{array}{l}32 \\
40 \% \\
12.8 \\
\mathbf{1 3}\end{array}$ & $\begin{array}{l}19 \\
40 \% \\
7.6 \\
8\end{array}$ & $\begin{array}{l}4 \\
80 \% \\
3.20 \\
3\end{array}$ & $\begin{array}{l}2 \\
80 \% \\
1.60 \\
2\end{array}$ \\
\hline & $\begin{array}{l}\text { Fatehabad } \\
\text { (Ftd, Ratiya } \\
\text { Tohana, } \\
\text { Bhattoo }\end{array}$ & $\begin{array}{l}427 \\
10 \% \\
42.7 \\
\mathbf{4 3}\end{array}$ & $\begin{array}{l}330 \\
10 \% \\
33.0 \\
\mathbf{3 3}\end{array}$ & $\begin{array}{l}32 \\
20 \% \\
6.4 \\
6\end{array}$ & $\begin{array}{l}19 \\
20 \% \\
3.8 \\
4\end{array}$ & $\begin{array}{l}24 \\
40 \% \\
9.6 \\
9\end{array}$ & $\begin{array}{l}16 \\
40 \% \\
6.4 \\
6\end{array}$ & $\begin{array}{l}1 \\
80 \% \\
.8 \\
1\end{array}$ & $\begin{array}{l}4 \\
80 \% \\
3.2 \\
\mathbf{3}\end{array}$ \\
\hline & $\begin{array}{l}\text { Jind } \\
\text { (Narwana) }\end{array}$ & $\begin{array}{l}87 \\
10 \% \\
8.7 \\
9 \\
\end{array}$ & $\begin{array}{l}67 \\
10 \% \\
6.70 \\
7 \\
\end{array}$ & $\begin{array}{l}7 \\
20 \% \\
1.40 \\
2\end{array}$ & $\begin{array}{l}4 \\
20 \% \\
.80 \\
1 \\
\end{array}$ & $\begin{array}{l}5 \\
40 \% \\
2.00 \\
2 \\
\end{array}$ & $\begin{array}{l}3 \\
40 \% \\
1.20 \\
1\end{array}$ & $\begin{array}{l}1 \\
80 \% \\
.80 \\
1 \\
\end{array}$ & $\begin{array}{l}0 \\
80 \% \\
0 \\
\mathbf{0}\end{array}$ \\
\hline & Total & $\begin{array}{l}2200 \\
10 \% \\
220.0 \\
\mathbf{2 2 0}\end{array}$ & $\begin{array}{l}1892 \\
10 \% \\
189.2 \\
\mathbf{1 8 9}\end{array}$ & $\begin{array}{l}219 \\
20 \% \\
43.8 \\
44\end{array}$ & $\begin{array}{l}126 \\
20 \% \\
25.2 \\
\mathbf{2 5}\end{array}$ & $\begin{array}{l}104 \\
40 \% \\
41.6 \\
42\end{array}$ & $\begin{array}{l}76 \\
40 \% \\
30.4 \\
\mathbf{3 0}\end{array}$ & $\begin{array}{l}14 \\
80 \% \\
11.2 \\
\mathbf{1 1}\end{array}$ & $\begin{array}{l}13 \\
80 \% \\
10.4 \\
\mathbf{1 1}\end{array}$ \\
\hline & Grand Total & \multicolumn{2}{|l|}{4092} & \multicolumn{2}{|l|}{345} & \multicolumn{2}{|l|}{181} & \multicolumn{2}{|l|}{27} \\
\hline & Sample Drawn & \multicolumn{2}{|c|}{$\begin{array}{l}10 \% \\
409.2 \\
\mathbf{4 0 9}(220+189) \\
\end{array}$} & \multicolumn{2}{|c|}{$\begin{array}{l}20 \% \\
69.0 \\
69(44+25)\end{array}$} & \multicolumn{2}{|c|}{$\begin{array}{l}40 \% \\
75.2 \\
72(42+30)\end{array}$} & \multicolumn{2}{|c|}{$\begin{array}{l}80 \% \\
21.6 \\
\mathbf{2 2}(11+11) \\
\end{array}$} \\
\hline & Sample size & \multicolumn{4}{|c|}{$409+69+72+22=572$} & & & & \\
\hline
\end{tabular}

Source: Election Department, Government of Haryana July, 2010

From the above table, it is clear in all Panchayats there are 4092 Panches and 345 Sarpanches. Further, Panchayat Samities have 181 members and Zila Parishad have 22 members. On combining these total sc members comes out to be 4645 
For convenience and to have sizeable numbers of respondents from each democratically elected body in the sample, a disproportions sample has been considered. For instance, 10\% from Panches, 20\% from Sarpanches, $40 \%$ from Panchayat Samities and 80\% from Zila Parishad has been drawn, which comes out to be 492 Panches; 69 Sarpanches; 72 Panchayat Samities members and 22 Zila Parishad members. The total size of sample is 572 members. The selection of respondents will be made on random sampling basis across Panchayat, Panchayat samities and Zila Parishad, keeping the disproportionate criteria in mind. The study unit, therefore, is SC's PRI's members in this study. Present study is based on primary and secondary data which will be from various sources. The secondary data (published and unpublished) will be also being collected from the different government and semi government publication.

\section{Result and Discussion:-}

We shall examine in brief the socio-economic background of the respondents. This is necessary because the various factor are more or less important in analyzing the behaviour and attitudinal patterns of the respondents. In view of the significance of socio-economic and demographic profiles, it can be stated that such an exercise not only bring out the various characteristics of the respondents for the benefit of readers, but also enable the researcher to analyze their responses and attitude in a more explicit and meaningful manner. This shall examine the demographic, social, educational, occupational and economic attributes of the respondents.

Table No.2:- Caste * Status in PRI's

\begin{tabular}{|c|c|c|c|c|c|c|}
\hline & & \multicolumn{4}{|c|}{ Type of member } & \multirow[t]{2}{*}{ Total } \\
\hline & & Panch & Sarpanch & $\begin{array}{c}\text { Block Samiti } \\
\text { Member }\end{array}$ & $\begin{array}{l}\text { Zila Parishad } \\
\text { Member }\end{array}$ & \\
\hline \multirow{18}{*}{ Caste } & \multirow[t]{2}{*}{ Chamar } & 202 & 31 & 36 & 14 & 283 \\
\hline & & $35.3 \%$ & $5.4 \%$ & $6.3 \%$ & $2.4 \%$ & $49.5 \%$ \\
\hline & \multirow{2}{*}{$\begin{array}{l}\text { Ramdasiya } \\
\text { Sikh }\end{array}$} & 39 & 4 & 8 & 4 & 55 \\
\hline & & $6.8 \%$ & $.7 \%$ & $1.4 \%$ & $.7 \%$ & $9.6 \%$ \\
\hline & \multirow[t]{2}{*}{ Balmiki } & 75 & 9 & 5 & 1 & 90 \\
\hline & & $13.1 \%$ & $1.6 \%$ & $.9 \%$ & $.2 \%$ & $15.7 \%$ \\
\hline & \multirow[t]{2}{*}{ Bazigar } & 17 & 7 & 6 & 1 & 31 \\
\hline & & $3.0 \%$ & $1.2 \%$ & $1.0 \%$ & $.2 \%$ & $5.4 \%$ \\
\hline & \multirow[t]{2}{*}{ Dhanak } & 26 & 3 & 3 & 0 & 32 \\
\hline & & $4.5 \%$ & $.5 \%$ & $.5 \%$ & $.0 \%$ & $5.6 \%$ \\
\hline & \multirow[t]{2}{*}{ Mahjabi Sikh } & 26 & 3 & 8 & 1 & 38 \\
\hline & & $4.5 \%$ & $.5 \%$ & $1.4 \%$ & $.2 \%$ & $6.6 \%$ \\
\hline & \multirow[t]{2}{*}{ Odd } & 2 & 4 & 1 & 1 & 8 \\
\hline & & $.3 \%$ & $.7 \%$ & $.2 \%$ & $.2 \%$ & $1.4 \%$ \\
\hline & \multirow[t]{2}{*}{ Sainsi } & 16 & 5 & 3 & 0 & 24 \\
\hline & & $2.8 \%$ & $.9 \%$ & $.5 \%$ & $.0 \%$ & $4.2 \%$ \\
\hline & \multirow[t]{2}{*}{ Kabir Panthi } & 6 & 3 & 2 & 0 & 11 \\
\hline & & $1.0 \%$ & $.5 \%$ & $.3 \%$ & $.0 \%$ & $1.9 \%$ \\
\hline \multirow{2}{*}{\multicolumn{2}{|c|}{ Total }} & 409 & 69 & 72 & 22 & 572 \\
\hline & & $71.5 \%$ & $12.1 \%$ & $12.6 \%$ & $3.8 \%$ & $100.0 \%$ \\
\hline \multicolumn{7}{|c|}{ Chi-Square Tests } \\
\hline & & & Value & Df & \multicolumn{2}{|c|}{ Asymp. Sig. (2-sided) } \\
\hline \multicolumn{3}{|c|}{ Pearson Chi-Square } & $40.970^{\mathrm{a}}$ & 24 & & \\
\hline
\end{tabular}

The Table No.2 show the relationship between caste of respondents and elected PRI's members. A caste having high percentage of elected PRI representatives is considered highly elected. Caste is the most important factor in influencing the consciousness of individuals. The total number of castes included in the current sample is nine (9) and the composition of the scheduled caste respondents reflects the variation to a great extent, in our study. Table No 1 present's details about caste-wise distribution of the respondents. Accordingly, the table reveals that the total scheduled caste of Haryana. The table show that as far as panch elections concerned, the caste Chamar (35.3\%) and Balmiki (13.1\%) out of nine castes have high percentage of elected members as panch and Ramdasiya Sikh (6.8\%), 
Dhanak (4.5\%), Majhabi Sikh each, Bazigar (3.0\%) and Sainsi (2.8\%), Kabir Panthi (1.0\%), Odd (.3\%) are in minimum numbers. Sarpanch election is concern 44.9\% Chamar, 5.4\% Balmiki, 1.6\% Bazigar 1.2\% and .9\% Sainsi has elected. The only .7 \% Ramdasiya Sikh, Odd each and .5\% Dhanak, Majhabi Sikh each has elected minimum. In Block Samities election, Chamar have highly elected as 6.3\% Block Samities Members. Ramdasiya Sikh, Majhabi Sikh (1.4\%) each and Bajigar (1.0\%), Balmiki (.9\%), Sainsi and Dhanak (.5\%) each, Kabir Panthi (.3\%) and Odd $(.2 \%)$ have elected in the Block Samities elections. In Zila Parishad election Chamar (2.4\%) have the maximum numbers and secondly is Ramdasiya Sikh (.7\%). Balmiki, Bazigar, Majhabi Sikh, and Odd have .2\% each elected members each. From the caste Dhanak, Sainsi and Kabir Panthi have no Zila Parishad Members have elected. The Chamar(49.5\%) out of total sample of 572 has highly elected in PRI's. The table No. 2 shows the relationship between caste and elected members. The value of the $\mathrm{p}=.017$ is lower than the level of significance 0.05 .

Table. No. 3:- Caste * Gender

\begin{tabular}{|c|c|c|c|c|}
\hline & & \multicolumn{2}{|c|}{ What is the gender of respondent? } & \multirow[t]{2}{*}{ Total } \\
\hline & & Male & Female & \\
\hline \multirow{8}{*}{ Caste } & \multirow[t]{2}{*}{ Chamar } & 165 & 118 & 283 \\
\hline & & $28.8 \%$ & $20.6 \%$ & $49.5 \%$ \\
\hline & \multirow[t]{2}{*}{ Ramdasiya Sikh } & 28 & 27 & 55 \\
\hline & & $4.9 \%$ & $4.7 \%$ & $9.6 \%$ \\
\hline & \multirow[t]{2}{*}{ Balmiki } & 39 & 51 & 90 \\
\hline & & $6.8 \%$ & $8.9 \%$ & $15.7 \%$ \\
\hline & \multirow[t]{2}{*}{ Bazigar } & 17 & 14 & 31 \\
\hline & & $3.0 \%$ & $2.4 \%$ & $5.4 \%$ \\
\hline & \multirow[t]{2}{*}{ Dhanak } & 19 & 13 & 32 \\
\hline \multirow{9}{*}{ Caste } & & $3.3 \%$ & $2.3 \%$ & $5.6 \%$ \\
\hline & \multirow[t]{2}{*}{ Mahjabi Sikh } & 25 & 13 & 38 \\
\hline & & $4.4 \%$ & $2.3 \%$ & $6.6 \%$ \\
\hline & \multirow[t]{2}{*}{ Odd } & 5 & 3 & 8 \\
\hline & & $.9 \%$ & $.5 \%$ & $1.4 \%$ \\
\hline & \multirow[t]{2}{*}{ Sainsi } & 12 & 12 & 24 \\
\hline & & $2.1 \%$ & $2.1 \%$ & $4.2 \%$ \\
\hline & \multirow[t]{2}{*}{ Kabir Panthi } & 7 & 4 & 11 \\
\hline & & $1.2 \%$ & $.7 \%$ & $1.9 \%$ \\
\hline \multirow{2}{*}{\multicolumn{2}{|c|}{ Total }} & 317 & 255 & 572 \\
\hline & & $55.4 \%$ & $44.6 \%$ & $100.0 \%$ \\
\hline \multicolumn{5}{|c|}{ Chi-Square Tests } \\
\hline & & Value & Df & Asymp. Sig. (2-sided) \\
\hline \multicolumn{2}{|c|}{ Pearson Chi-Square } & $9.336^{\mathrm{a}}$ & 8 & .315 \\
\hline
\end{tabular}

The Table No.3 shows the relationship between caste of respondents and their gender using Chi square test. Chamar (28.8\%) have maximum respondents have from the male gender. $6.8 \%$ respondents are belongs to Balmiki caste. 4.9, 4.4, 3.3\% respondents are laying between in Ramdasiya Sikh, Majhabi Sikh, and Dhanak castes. The only $2.1 \%$ Sainsi, 1.2\% Kabir Panthi, .9\% Odd are belong to male category. Female respondents of Chamar, Balmiki, Ramdasiya Sikh, Bazigar, Dhanak, Majhabi Sikh are the 20.6\%, 8.9\%, 4.7\%, 2.4\% and 2.3\% each, respectively. The Chamar respondents having majority in $49.5 \%$ ( $28.8 \%$ male +20.6 female) out of total from the all caste included in this. Table No 3 don't show the relationship between caste and gender. The value of $p=.315$ is greater than level of significance 0.05 . All castes were included from male and female category. 
Table. No. 4:- Caste *Age

\begin{tabular}{|c|c|c|c|c|c|c|c|}
\hline & & \multicolumn{5}{|c|}{ What is the age of the respondent? } & \multirow[t]{2}{*}{ Total } \\
\hline & & $\begin{array}{c}\text { Up to } 29 \\
\text { years }\end{array}$ & $\begin{array}{c}30 \text { to } 39 \\
\text { years }\end{array}$ & $\begin{array}{c}40 \text { to } 49 \\
\text { years }\end{array}$ & $\begin{array}{c}50 \text { to } 59 \\
\text { years }\end{array}$ & 60 and above & \\
\hline \multirow{18}{*}{ Caste } & \multirow[t]{2}{*}{ Chamar } & 34 & 104 & 77 & 47 & 21 & 283 \\
\hline & & $5.9 \%$ & $18.2 \%$ & $13.5 \%$ & $8.2 \%$ & $3.7 \%$ & $49.5 \%$ \\
\hline & \multirow{2}{*}{$\begin{array}{c}\text { Ramdasiya } \\
\text { Sikh }\end{array}$} & 7 & 20 & 10 & 12 & 6 & 55 \\
\hline & & $1.2 \%$ & $3.5 \%$ & $1.7 \%$ & $2.1 \%$ & $1.0 \%$ & $9.6 \%$ \\
\hline & Balmiki & 17 & 31 & 25 & 15 & 2 & 90 \\
\hline & & $3.0 \%$ & $5.4 \%$ & $4.4 \%$ & $2.6 \%$ & $.3 \%$ & $15.7 \%$ \\
\hline & Bazigar & 3 & 12 & 8 & 7 & 1 & 31 \\
\hline & & $.5 \%$ & $2.1 \%$ & $1.4 \%$ & $1.2 \%$ & $.2 \%$ & $5.4 \%$ \\
\hline & Dhanak & 3 & 9 & 11 & 7 & 2 & 32 \\
\hline & & $.5 \%$ & $1.6 \%$ & $1.9 \%$ & $1.2 \%$ & $.3 \%$ & $5.6 \%$ \\
\hline & Mahjabi & 5 & 12 & 9 & 11 & 1 & 38 \\
\hline & Sikh & $.9 \%$ & $2.1 \%$ & $1.6 \%$ & $1.9 \%$ & $.2 \%$ & $6.6 \%$ \\
\hline & Odd & 2 & 2 & 2 & 2 & 0 & 8 \\
\hline & & $.3 \%$ & $.3 \%$ & $.3 \%$ & $.3 \%$ & $.0 \%$ & $1.4 \%$ \\
\hline & Sainsi & 3 & 6 & 9 & 3 & 3 & 24 \\
\hline & & $.5 \%$ & $1.0 \%$ & $1.6 \%$ & $.5 \%$ & $.5 \%$ & $4.2 \%$ \\
\hline & Kabir & 0 & 5 & 4 & 2 & 0 & 11 \\
\hline & Panthi & $.0 \%$ & $.9 \%$ & $.7 \%$ & $.3 \%$ & $.0 \%$ & $1.9 \%$ \\
\hline & otal & 74 & 201 & 155 & 106 & 36 & 572 \\
\hline & & $12.9 \%$ & $35.1 \%$ & $27.1 \%$ & $18.5 \%$ & $6.3 \%$ & $100.0 \%$ \\
\hline & & & & Square Test & & & \\
\hline & & & Value & \begin{tabular}{l|l} 
Df & \\
\end{tabular} & & Sig. (2-sided) & \\
\hline & son Chi-Squa & & $24.658^{\mathrm{a}}$ & 32 & & .820 & \\
\hline & a. 20 cells & $4 \%$ ) hav & e expected co & less than 5 . & nimum & ed count is .50 & \\
\hline
\end{tabular}

In Indian society, age is one of the most important determinants of social status, role and social responsibility. In traditional societies, in view of the wider knowledge and experience, the old people are given more respect in comparison to young. But in the modern time, there are social, economic, political changes in authority of the older people pertaining to the operation and conduct in socio-economic activities has replaced by younger generation. Age has been considered as an important variable, which has been classified into five categories-i.e. up to 29,3039,40-49,50-59 and 60 and above. Table No. 4 exhibit that respondents Chamar (5.9\%), Balmiki (3.0\%), Ramdasiya Sikh (1.2\%) and Majhabi Sikh (.9\%), Bazigar, Dhanak,and Sainsi (.5\%) each are lying in age group of up to 29 years group. No one has come from Kabir Panthi (.0\%) caste. In the age group of 30 to 39 years, Chamar (18.2\%), Balmiki (5.4\%), Ramdasiya Sikh (3.5\%) and Majhabi Sikh, Bazigar (2.1\%), Dhanak (1.6\%), Sainsi (1.0\%), Kabir Panthi $(.9 \%)$, Odd (.3) are admitted in it. In age group 40 to 49 years the respondents belong to the Chamar (13.5\%), Balmiki (4.4\%), Dhanak (1.9\%), Ramdasiya Sikh (1.7\%), Sainsi $(1.6 \%)$ are in maximum numbers and Kabir Panthi $(.7 \%)$ and Odd $(.3 \%)$ are in minimum numbers. Age group of 50 to 59 years, Chamar caste $(8.2 \%)$ have in majority and Sainsi $(.5 \%)$, Kabir Panthi, Odd $(.3 \% 0$ each have lowest number respondents. In the age group of 60 and avow Odd (.0\%) and Kabir Pnathi (.0\%) have no respondents and Chamar $(3.7 \%)$ are maximum numbers. Half of the respondents lie between in the two group 30 to 39 and 40 to 49 years. The Table No. 4 shows that there were no relationship between caste and age groups. The value of $\mathrm{p}=.820$ is greater than the level of significance 0.05 . 
Table. No. 5 :- Caste *Education

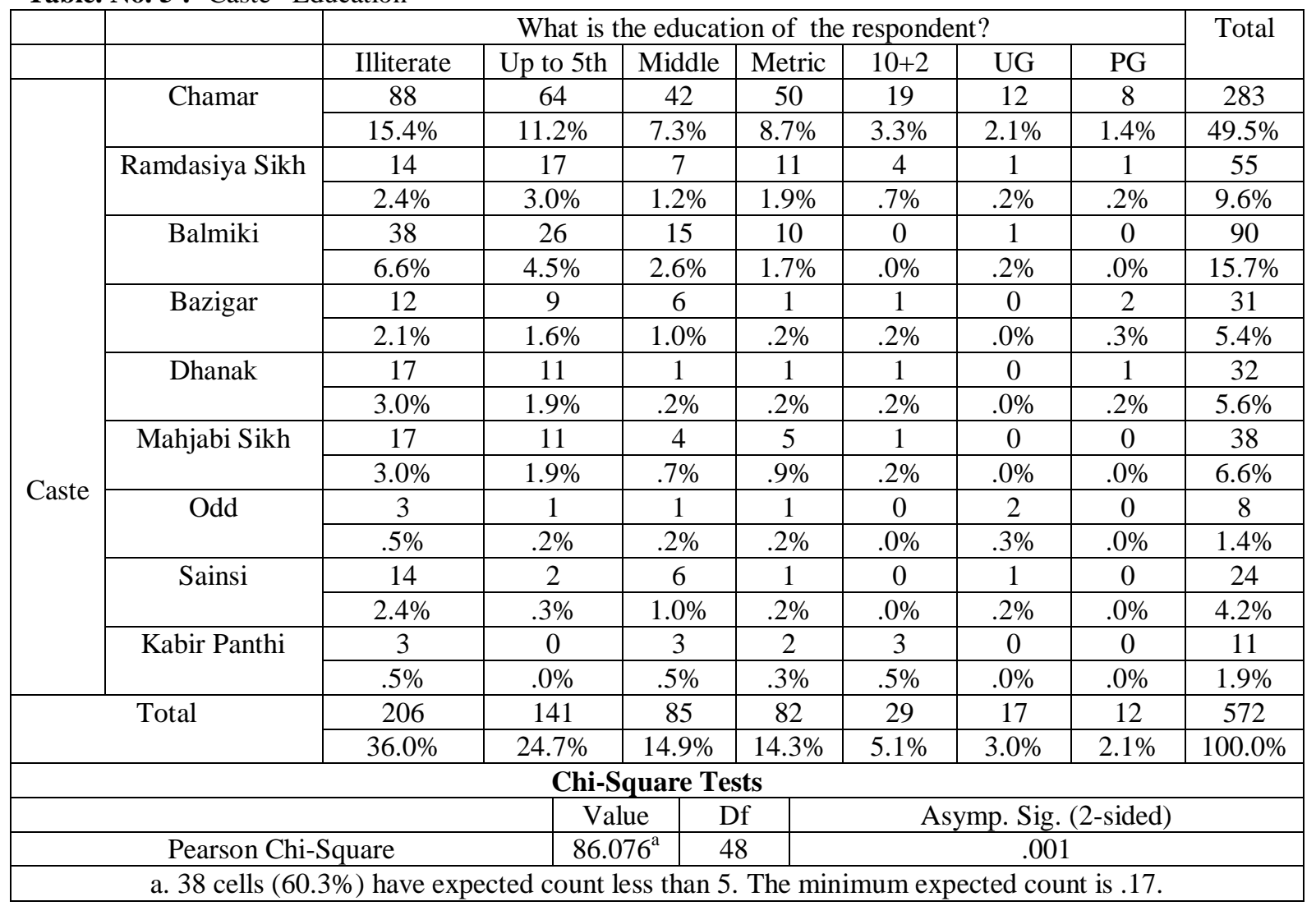

The Table No.5 shows the relationship between caste and education standard of respondents. Education category are divided in seven category, i.e., illiterate, up to 5th, middle, metric 12th, UG and PG. Chamar (15.4\%) have highly illiterate respondents. Dhanak, Majhabi Sikh, Sainsi, Ramdasiya Sikh, Odd, Kabir Panthi are 3.0\% each, $2.4 \%$, each and $.5 \%$ each respectively. The Chamar (11.2\%), Balmiki (4.5\%) and Ramdasiya Sikh (3.0\%) are numerically high and Majhabi Sikh, Dhanak (1.9\%), Odd (.2\%), Kabir Panthi (.0\%) are numerically low in education standard of up to 5th standard. $7.3 \%$ Chamar, and 2.6\% Balmiki are highly Middle passed respondents and Ramdasiya Sikh (1.2\%), Sainsi, Bazigar (1.0\%), Dhanak and Odd (.2\%) are lower Middle passes. Chamar (8.7\%), Ramdasiya Sikh $(1.9 \%)$ and Balmiki (1.7\%) are highly metric passed and Majhabi Sikh (.9\%), Kabir Panthi (.3\%), Bazigar, Dhanak, Odd, Sainsi (.2\%) are numerically low metric passed. Chamar (3.3\%), Ramdasiya Sikh (.7\%) and Kabir Panthi $(.5 \%)$ are highly $10+2$ passed and Bazigar, Dhanak, Majhabi Sikh earch are $.2 \%$ minimum passed. From the Balmiki, Odd, and Sainsi $(.0 \%)$ castes no one has passed the 10+2 classes. Chamar (2.1\%) are highly UG passed and Odd(.3\%), Ramdasiya Sikh, Balmiki (.2\%) each are numerically low UG passed. From the Bazigar, Dhanak, Majhabi Sikh, Kabir Panthi $(.0 \%)$ have no found UG Passed. Chamar $(1.4 \%)$ are highly PG passed and .3\% Bazigar, .2\% Ramdasiya Sikh, Dhanak each are numerically PG passed. Balmiki, Majhabi Sikh, Odd, Sainsi, and Kabir Panthi $(.0 \%)$ castes have no PG classes passed. The Table No. 5 shows that there is the relationship between caste and education. The value of $\mathrm{p}=.001$ is lower than the level of significance .005 . 
Table. No. 6:- Caste *Occupation

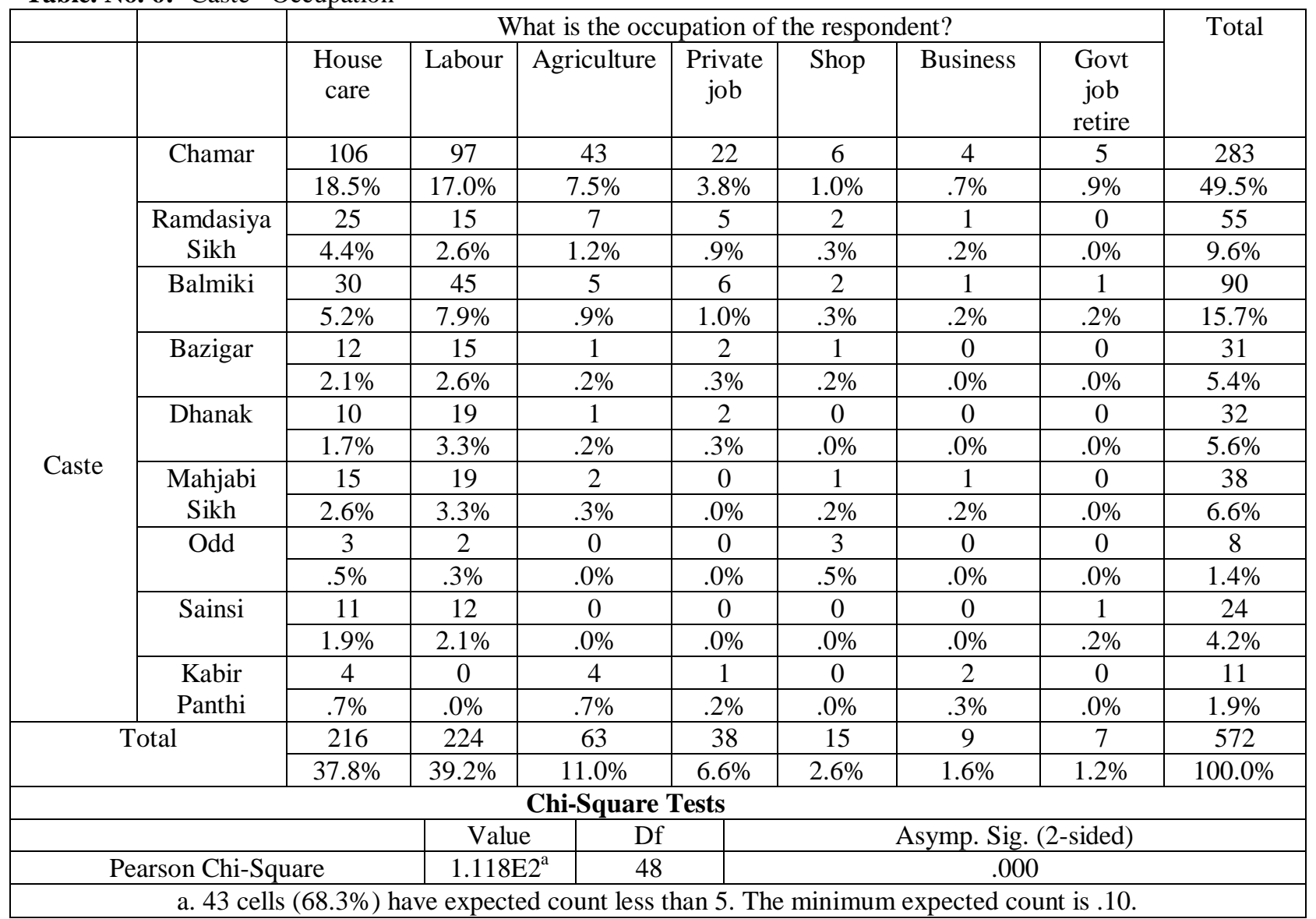

The Table No.6 shows the relationship between caste and occupation of the respondents. Chamar (18.5\%), Balmiki $(5.2 \% \%)$, Ramdasiya Sikh (4.4\%), Majhabi Silk (2.6\%), Bazigar (2.1\%), and Sainsi (1.9\%) are the house carer. Most of the respondents from the Chamar (17.0\%), Balmiki (7.9\%), Dhanak and Majhabi Sikh(3.3\%) each are the labourer. No one from the caste Kabir Panthi were doing labour. 7.5\%, 1.2\%, .9\%, and .7\% Chamar, Ramdasiya Sikh, Baziagr and Kabir Panthi, are the agriculturist. On one from Odd and Sainsi was agriculturist. Chamar (3.8\%), Balmiki (1.0\%), Ramdasiya Sikh (.9\%), Bazigar and Dhanak each (.3\%) are in private job and Majhabi Sikh, Odd, and Sainsi were not in private job. Dhanak, Sainsi and Kabir Panthi are not in the shopping occupation. Dhanak, Odd and Bazigar are not in business and govt job retire background. Sainsi is the only caste which is not in agriculture, private job, shopkeeper, and business man. Chamar $(.7 \%)$ are the most of the businessman. Chamar (.9\%), Balmiki and Sainsi (.2\%) each are the govt job retire background. Ramdasiya Sikh, Bazigar, Dhanak, Majhabi Sikh, Odd and Kabir Panthi are not in govt job retire background. The Table No. 6shows that there is the relationship between caste and occupation. The value of $\mathrm{p}=.000$ is lower than the level of significance .005 . 
Table. No.7:- Caste *Structure of Agriculture

\begin{tabular}{|c|c|c|c|c|c|c|c|c|}
\hline & & \multicolumn{6}{|c|}{ What is the structure of agriculture? } & \multirow[t]{2}{*}{ Total } \\
\hline & & $\begin{array}{l}\text { Up to } 2 \\
\text { acre }\end{array}$ & 2 to 4 acre & $\begin{array}{c}4 \text { to } 6 \\
\text { acre }\end{array}$ & $\begin{array}{l}6 \text { to } 8 \\
\text { acre }\end{array}$ & 8 to above & No land & \\
\hline \multirow{2}{*}{\multicolumn{2}{|c|}{ Chamar }} & 40 & 25 & 11 & 6 & 7 & 194 & 283 \\
\hline & & $7.0 \%$ & $4.4 \%$ & $1.9 \%$ & $1.0 \%$ & $1.2 \%$ & $33.9 \%$ & $49.5 \%$ \\
\hline & \multirow{2}{*}{$\begin{array}{c}\text { Ramdasiya } \\
\text { Sikh }\end{array}$} & 11 & 3 & 2 & 0 & 0 & 39 & 55 \\
\hline & & $1.9 \%$ & $.5 \%$ & $.3 \%$ & $.0 \%$ & $.0 \%$ & $6.8 \%$ & $9.6 \%$ \\
\hline & \multirow[t]{2}{*}{ Balmiki } & 5 & 1 & 1 & 1 & 0 & 82 & 90 \\
\hline & & $.9 \%$ & $.2 \%$ & $.2 \%$ & $.2 \%$ & $.0 \%$ & $14.3 \%$ & $15.7 \%$ \\
\hline & \multirow[t]{2}{*}{ Bazigar } & 6 & 3 & 0 & 0 & 0 & 22 & 31 \\
\hline & & $1.0 \%$ & $.5 \%$ & $.0 \%$ & $.0 \%$ & $.0 \%$ & $3.8 \%$ & $5.4 \%$ \\
\hline & \multirow[t]{2}{*}{ Dhanak } & 3 & 1 & 0 & 1 & 0 & 27 & 32 \\
\hline \multirow{9}{*}{ Caste } & & $.5 \%$ & $.2 \%$ & $.0 \%$ & $.2 \%$ & $.0 \%$ & $4.7 \%$ & $5.6 \%$ \\
\hline & \multirow{2}{*}{$\begin{array}{c}\text { Mahjabi } \\
\text { Sikh } \\
\end{array}$} & 4 & 2 & 0 & 0 & 1 & 31 & 38 \\
\hline & & $.7 \%$ & $.3 \%$ & $.0 \%$ & $.0 \%$ & $.2 \%$ & $5.4 \%$ & $6.6 \%$ \\
\hline & \multirow[t]{2}{*}{ Odd } & 1 & 0 & 1 & 0 & 0 & 6 & 8 \\
\hline & & $.2 \%$ & $.0 \%$ & $.2 \%$ & $.0 \%$ & $.0 \%$ & $1.0 \%$ & $1.4 \%$ \\
\hline & \multirow[t]{2}{*}{ Sainsi } & 3 & 0 & 0 & 0 & 0 & 21 & 24 \\
\hline & & $.5 \%$ & $.0 \%$ & $.0 \%$ & $.0 \%$ & $.0 \%$ & $3.7 \%$ & $4.2 \%$ \\
\hline & \multirow{2}{*}{$\begin{array}{l}\text { Kabir } \\
\text { Panthi }\end{array}$} & 2 & 0 & 3 & 0 & 1 & 5 & 11 \\
\hline & & $.3 \%$ & $.0 \%$ & $.5 \%$ & $.0 \%$ & $.2 \%$ & $.9 \%$ & $1.9 \%$ \\
\hline \multirow{2}{*}{\multicolumn{2}{|c|}{ Total }} & 75 & 35 & 18 & 8 & 9 & 427 & 572 \\
\hline & & $13.1 \%$ & $6.1 \%$ & $3.1 \%$ & $1.4 \%$ & $1.6 \%$ & $74.7 \%$ & $100.0 \%$ \\
\hline \multicolumn{9}{|c|}{ Chi-Square Tests } \\
\hline & & & Value & $\mathrm{df}$ & \multicolumn{4}{|c|}{ Asymp. Sig. (2-sided) } \\
\hline \multicolumn{3}{|c|}{ Pearson Chi-Square } & $67.816^{\mathrm{a}}$ & 40 & \multicolumn{4}{|c|}{.004} \\
\hline
\end{tabular}

The Table No. 7 shows the relationship between caste and structure of agriculture of respondents. Chamar (7.0\%), Ramdasiya Sikh (1.9\%), Bazigar (1.0\%), Balmiki ( $.9 \%)$ having the up to 2 acre agriculture land. Majhabi Sikh (.7\%), Dhanak, Sainsi (.5\%) each, and Odd (.2\%) having minimum agriculture sect of up to 2 acre. Chamar and Bazigar, Ramdasiya Sikh having the $4.4 \%, .5 \%$ each have land 2 to 4 acre. Kabir Panthi, Odd, Sainsi have no the agriculture land 2 to 4 acre. Bazigar Dhanak, Majhabi Sikh and Sainsi have no the agriculture land 4 to 6 acre. Only the Chamar (1.9\%), Kabir Panthi (.5\%), Ramdasiya Sikh (.3\%) and Balmiki, Odd (.5\%) each having agriculture land 4 to 6 acre. Bazigar, Majhabi Sikh, Odd, Sainsi have not the agriculture sect 6 to 8 acre. Chamar (1.0\%), Balmiki and Dhanak (.2\%) each having 6 to 8 acre agriculture land. Chamar (1.2\%), Majhabi Sikh and Kabir Panthi (.2\%) each having 8 to above agriculture land. Chamar (33.9\%), Balmiki (14.3\%), Ramdasiya Sikh ( 6.8\%), Dhanak ( 4.7\%), Sainsi (3.7\%), and Kabir Panthi (.9\%) have no agriculture land. The Table No. 7 shows the positive correlation between caste and agriculture of respondent. The value of $\mathrm{p}=0.04$ is lower than the level of significance 0.05 . 
Table. No. 8:- Caste *Income

\begin{tabular}{|c|c|c|c|c|c|c|c|c|c|}
\hline & & \multicolumn{7}{|c|}{ What is the total income of the respondent family? } & \multirow[t]{2}{*}{ Total } \\
\hline & & $\begin{array}{l}\text { Up to } \\
40000\end{array}$ & $\begin{array}{l}\text { Up to } \\
60000\end{array}$ & $\begin{array}{l}\text { Up to } \\
80000\end{array}$ & $\begin{array}{c}\text { Up To I } \\
\text { Lakh }\end{array}$ & $\begin{array}{l}\text { Up to } 2 \\
\text { Lakh }\end{array}$ & $\begin{array}{c}\text { Up to } 3 \\
\text { Lakh }\end{array}$ & $\begin{array}{c}4 \text { Lakh and } \\
\text { above }\end{array}$ & \\
\hline \multirow{18}{*}{ Caste } & \multirow[t]{2}{*}{ Chamar } & 5 & 105 & 89 & 51 & 2 & 17 & 14 & 283 \\
\hline & & $.9 \%$ & $18.4 \%$ & $15.6 \%$ & $8.9 \%$ & $.3 \%$ & $3.0 \%$ & $2.4 \%$ & $49.5 \%$ \\
\hline & \multirow{2}{*}{$\begin{array}{l}\text { Ramdasi } \\
\text { ya Sikh }\end{array}$} & 0 & 20 & 18 & 8 & 1 & 5 & 3 & 55 \\
\hline & & $.0 \%$ & $3.5 \%$ & $3.1 \%$ & $1.4 \%$ & $.2 \%$ & $.9 \%$ & $.5 \%$ & $9.6 \%$ \\
\hline & \multirow{2}{*}{ Balmiki } & 3 & 46 & 20 & 17 & 1 & 2 & 1 & 90 \\
\hline & & $.5 \%$ & $8.0 \%$ & $3.5 \%$ & $3.0 \%$ & $.2 \%$ & $.3 \%$ & $.2 \%$ & $15.7 \%$ \\
\hline & \multirow[t]{2}{*}{ Bazigar } & 0 & 13 & 11 & 6 & 0 & 0 & 1 & 31 \\
\hline & & $.0 \%$ & $2.3 \%$ & $1.9 \%$ & $1.0 \%$ & $.0 \%$ & $.0 \%$ & $.2 \%$ & $5.4 \%$ \\
\hline & \multirow[t]{2}{*}{ Dhanak } & 0 & 12 & 16 & 3 & 0 & 1 & 0 & 32 \\
\hline & & $.0 \%$ & $2.1 \%$ & $2.8 \%$ & $.5 \%$ & $.0 \%$ & $.2 \%$ & $.0 \%$ & $5.6 \%$ \\
\hline & \multirow{2}{*}{$\begin{array}{c}\text { Mahjabi } \\
\text { Sikh }\end{array}$} & 1 & 14 & 17 & 5 & 0 & 0 & 1 & 38 \\
\hline & & $.2 \%$ & $2.4 \%$ & $3.0 \%$ & $.9 \%$ & $.0 \%$ & $.0 \%$ & $.2 \%$ & $6.6 \%$ \\
\hline & \multirow[t]{2}{*}{ Odd } & 0 & 0 & 5 & 0 & 1 & 1 & 1 & 8 \\
\hline & & $.0 \%$ & $.0 \%$ & $.9 \%$ & $.0 \%$ & $.2 \%$ & $.2 \%$ & $.2 \%$ & $1.4 \%$ \\
\hline & \multirow[t]{2}{*}{ Sainsi } & 1 & 13 & 6 & 2 & 0 & 1 & 1 & 24 \\
\hline & & $.2 \%$ & $2.3 \%$ & $1.0 \%$ & $.3 \%$ & $.0 \%$ & $.2 \%$ & $.2 \%$ & $4.2 \%$ \\
\hline & \multirow{2}{*}{$\begin{array}{c}\text { Kabir } \\
\text { Panthi }\end{array}$} & 0 & 3 & 4 & 3 & 0 & 1 & 0 & 11 \\
\hline & & $.0 \%$ & $.5 \%$ & $.7 \%$ & $.5 \%$ & $.0 \%$ & $.2 \%$ & $.0 \%$ & $1.9 \%$ \\
\hline \multirow{2}{*}{\multicolumn{2}{|c|}{ Total }} & 10 & 226 & 186 & 95 & 5 & 28 & 22 & 572 \\
\hline & & $1.7 \%$ & $39.5 \%$ & $32.5 \%$ & $16.6 \%$ & $.9 \%$ & $4.9 \%$ & $3.8 \%$ & $100.0 \%$ \\
\hline \multicolumn{10}{|c|}{ Chi-Square Tests } \\
\hline & & & \multicolumn{2}{|c|}{ Value } & if & \multicolumn{4}{|c|}{ Asymp. Sig. (2-sided) } \\
\hline \multicolumn{3}{|c|}{ Pearson Chi-Square } & \multirow{2}{*}{\multicolumn{2}{|c|}{\begin{tabular}{|c|}
$58.745^{\mathrm{a}}$ \\
ave expected coun
\end{tabular}}} & \begin{tabular}{l|l}
48 & \\
48 & 0 \\
\end{tabular} & \multicolumn{4}{|c|}{.138} \\
\hline \multicolumn{8}{|c|}{ a. 41 cells $(65.1 \%)$ have expected count less than 5 . The minimum expected count is .07 . } & & \\
\hline
\end{tabular}

The Table No.8 and shows the relationship between caste and income of respondent family. The Chamar (.9\%), Balmiki (.5\%) have up to 40000rs income per year and Ramdasiya Sikh, Bazigar, Dhanak, Odd and Kabir Panthi (.0\%) each have no income such this type. The income up to 60000 have the castes Chamar (18.4\%), Balmiki (8.0\%), Ramdasiya Sikh (3.5\%) and Bazigar, Sainsi $(2.3 \%)$ each. No one have from the Caste Odd (.0\%) having income up to 60000rs. Chamar (15.6\%) have highest income up to 80000rs per year. Balmiki, Ramdasiya Sikh, Majhabi Sikh, Dhanak, Sainsi, Odd, Kabir Panthi, 3.5\%, 3.1\%, 3.0\%, 2.8\%, 1.0\%, .9\%, .7\% have maximum income up to 80000 rs per year. $8.9 \%$ Chamar and 3.0\% Balmiki have the income up to one lakh and no one have come from the Odd caste in this group of income. .3\% Chamar have income group up to 2 lakh and Bazigar, Dhanak, Majhabi Sikh, Sainsi, Kabir Panthi have not this income group. Up to 3 lakh income group Chamar (3.0\%) have the highest percentage. Bazigar and Majhabi Sikh have not in income group up to 3 lakh. In the income group 4 lakh and above, Chamar (2.4\%) are the maximum and Dhanak, Kabir Panthi (.0\%) each have no percentage in this group. The Table No. 8 shows that there is no relationship between caste and income of respondent. Because the value of $p=.138$ is highest from the value of significance 0.05 . 
Table. No. 9:- Caste *Structure of Family

\begin{tabular}{|c|c|c|c|c|}
\hline & & \multicolumn{2}{|c|}{ What is the structure of respondent family? } & \multirow[t]{2}{*}{ Total } \\
\hline & & Joint family & Nuclear family & \\
\hline \multirow{18}{*}{ Caste } & \multirow[t]{2}{*}{ Chamar } & 136 & 147 & 283 \\
\hline & & $23.8 \%$ & $25.7 \%$ & $49.5 \%$ \\
\hline & \multirow[t]{2}{*}{ Ramdasiya Sikh } & 28 & 27 & 55 \\
\hline & & $4.9 \%$ & $4.7 \%$ & $9.6 \%$ \\
\hline & \multirow[t]{2}{*}{ Balmiki } & 54 & 36 & 90 \\
\hline & & $9.4 \%$ & $6.3 \%$ & $15.7 \%$ \\
\hline & \multirow[t]{2}{*}{ Bazigar } & 13 & 18 & 31 \\
\hline & & $2.3 \%$ & $3.1 \%$ & $5.4 \%$ \\
\hline & \multirow[t]{2}{*}{ Dhanak } & 15 & 17 & 32 \\
\hline & & $2.6 \%$ & $3.0 \%$ & $5.6 \%$ \\
\hline & \multirow[t]{2}{*}{ Mahjabi Sikh } & 14 & 24 & 38 \\
\hline & & $2.4 \%$ & $4.2 \%$ & $6.6 \%$ \\
\hline & \multirow[t]{2}{*}{ Odd } & 2 & 6 & 8 \\
\hline & & $.3 \%$ & $1.0 \%$ & $1.4 \%$ \\
\hline & \multirow[t]{2}{*}{ Sainsi } & 9 & 15 & 24 \\
\hline & & $1.6 \%$ & $2.6 \%$ & $4.2 \%$ \\
\hline & \multirow{2}{*}{ Kabir Panthi } & 7 & 4 & 11 \\
\hline & & $1.2 \%$ & $.7 \%$ & $1.9 \%$ \\
\hline \multirow{2}{*}{\multicolumn{2}{|c|}{ Total }} & 278 & 294 & 572 \\
\hline & & $48.6 \%$ & $51.4 \%$ & $100.0 \%$ \\
\hline \multicolumn{5}{|c|}{ Chi-Square Tests } \\
\hline \multirow{2}{*}{\multicolumn{2}{|c|}{ Pearson Chi-Square }} & \begin{tabular}{l|l} 
Value & \\
\end{tabular} & \multicolumn{2}{|c|}{ Asymp. Sig. (2-sided) } \\
\hline & & $11.488^{\mathrm{a}}$ & \multicolumn{2}{|c|}{.176} \\
\hline
\end{tabular}

The Table No.9 shows the relationship between caste and structure of respondent family. Chamar, Balmiki, Ramdasiya Sikh Dhanak, Majhabi Sikh, are living in joint family continuously 23.8, 9.4, 4.9, 2.6, and 2.4\%. Chamar, Balmiki, Ramdasiya Sikh, Majhabi Sikh and Sainsi, 25.7, 6.3, 4.7, 4.2, and 2.6\% are mostly living in nuclear family. The Table No.9 shows that there is no relationship between caste and structure of family of respondent. Because the value of $\mathrm{p}=.0176$ is highest from the value of significance 0.05 .

Table No. 10:- Caste *Type of house

\begin{tabular}{|c|c|c|c|c|c|c|}
\hline & & \multicolumn{4}{|c|}{ Type of house of respondents? } & \multirow[t]{2}{*}{ Total } \\
\hline & & $\begin{array}{c}\text { Kachha } \\
\text { house }\end{array}$ & $\begin{array}{c}\text { Semi Kachha } \\
\text { house }\end{array}$ & $\begin{array}{c}\text { Semi Pakka } \\
\text { house }\end{array}$ & $\begin{array}{l}\text { Pakka house with } \\
\text { separate toilet }\end{array}$ & \\
\hline & \multirow[t]{2}{*}{ Chamar } & 2 & 51 & 91 & 139 & 283 \\
\hline & & $.3 \%$ & $8.9 \%$ & $15.9 \%$ & $24.3 \%$ & $49.5 \%$ \\
\hline & \multirow{2}{*}{$\begin{array}{l}\text { Ramdasiya } \\
\text { Sikh }\end{array}$} & 0 & 7 & 16 & 32 & 55 \\
\hline & & $.0 \%$ & $1.2 \%$ & $2.8 \%$ & $5.6 \%$ & $9.6 \%$ \\
\hline & \multirow[t]{2}{*}{ Balmiki } & 2 & 28 & 19 & 41 & 90 \\
\hline & & $.3 \%$ & $4.9 \%$ & $3.3 \%$ & $7.2 \%$ & $15.7 \%$ \\
\hline & \multirow[t]{2}{*}{ Bazigar } & 0 & 5 & 9 & 17 & 31 \\
\hline \multirow{9}{*}{ Caste } & & $.0 \%$ & $.9 \%$ & $1.6 \%$ & $3.0 \%$ & $5.4 \%$ \\
\hline & \multirow[t]{2}{*}{ Dhanak } & 4 & 8 & 11 & 9 & 32 \\
\hline & & $.7 \%$ & $1.4 \%$ & $1.9 \%$ & $1.6 \%$ & $5.6 \%$ \\
\hline & \multirow[t]{2}{*}{ Mahjabi Sikh } & 0 & 10 & 19 & 9 & 38 \\
\hline & & $.0 \%$ & $1.7 \%$ & $3.3 \%$ & $1.6 \%$ & $6.6 \%$ \\
\hline & \multirow[t]{2}{*}{ Odd } & 0 & 0 & 3 & 5 & 8 \\
\hline & & $.0 \%$ & $.0 \%$ & $.5 \%$ & $.9 \%$ & $1.4 \%$ \\
\hline & \multirow[t]{2}{*}{ Sainsi } & 0 & 5 & 12 & 7 & 24 \\
\hline & & $.0 \%$ & $.9 \%$ & $2.1 \%$ & $1.2 \%$ & $4.2 \%$ \\
\hline
\end{tabular}




\begin{tabular}{|c|c|c|c|c|c|}
\hline \multirow[t]{2}{*}{ Kabir Panthi } & 0 & 1 & 2 & 8 & 11 \\
\hline & $.0 \%$ & $.2 \%$ & $.3 \%$ & $1.4 \%$ & $1.9 \%$ \\
\hline \multirow[t]{2}{*}{ Total } & 8 & 115 & 182 & 267 & 572 \\
\hline & $1.4 \%$ & $20.1 \%$ & $31.8 \%$ & $46.7 \%$ & $100.0 \%$ \\
\hline \multicolumn{6}{|c|}{ Chi-Square Tests } \\
\hline & Value & $\mathrm{df}$ & \multicolumn{3}{|c|}{ Asymp. Sig. (2-sided) } \\
\hline Pearson Chi-Square & $66.437^{\mathrm{a}}$ & 24 & \multicolumn{3}{|c|}{.000} \\
\hline
\end{tabular}

The Table No. 10 shows the relationship between caste and type of house of respondents, which gives clear indications that people who lives in Mud wall thatched roof, they are belong to the caste like, Dhanak (.7\%), Balmiki, Chamar (.3\%). The caste like Majhabi Sikh, Sainsi, Bazigar and Ramdasiya Sikh, Odd, Kabir Panthi have no Mud wall thatched roof house. 8.9\% Chamar and 4.9\% Balmiki and 1.7\% Majhabi Sikh, $1.4 \%$ Dhanak, .9\% Bazigar, Sainsi each, have lives in brick wall roof house. No one have the lives in brick wall roof house from the Odd caste. Chamar (15.9\%), Balmiki, Majhabi Sikh (3.3\%) each, Ramdasiya Sikh (2.8\%) and 2.1\% Sainsi are having the Brick wall tiled rooms. 24.3\% Chamar, 7.2\% Balmiki, and 5.6\% Ramdasiya Sikh are livening in Pakka house with separate toilet, bathroom and RCC roof. Majority of the respondents i.e. approximately $50 \%$ were lived in Pakka house with separate toilet, bathroom and RCC roof in each castes from the selected sample. The table No. 10 shows the relationship between caste and type of house of respondents. The value of $p=.000$ is less than value of level of significance 0.05 . Highly percentage of separate bathroom and toilets with RCC roof were economically strongly and with mud wall and brick rooms were weakly.

Table. No. 11:- Caste *Goodness

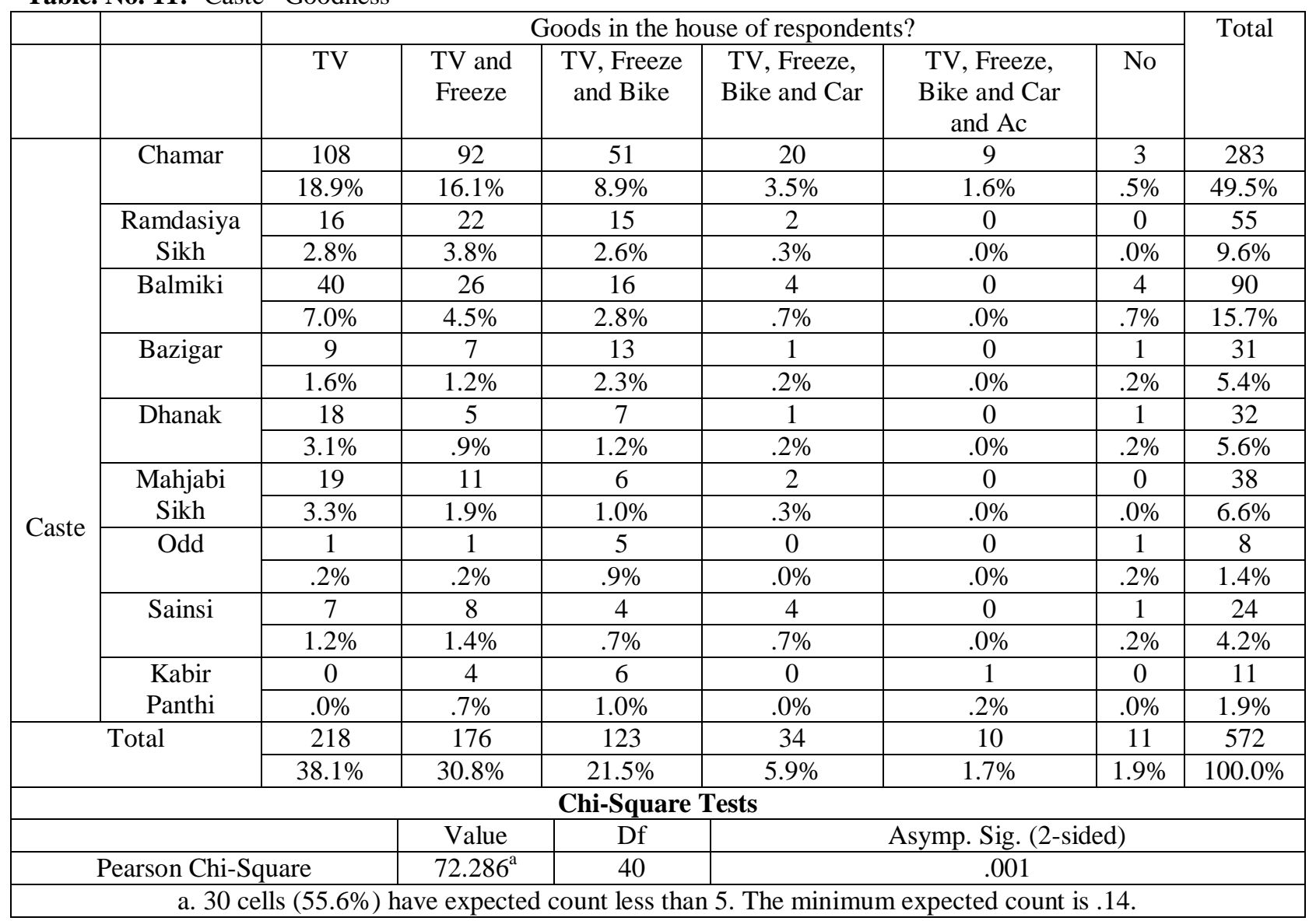

The Table No. 11shows the relationship between caste and goodness in the houses of respondents. Out of the nine castes respondents except the Kabir Panthi (.0\%), having the TV, Chamar (18.9\%), Balmiki (7.0\%), Majhabi Sikh 
(3.3\%), Dhanak (3.1\%) and Raadasiya Sikh (2.8\%), and Odd (.2\%). Chamar (16.1\%), Balmiki (2.8\%), Ramdasiya Sikh (3.8\%), Majhabi Sikh (1.9\%), and Odd (.2\%) having the TV and Freeze. TV, Freeze, and Bike are having in these caste, Chamar (8.9\%), Balmiki (2.8\%), Ramdasiya Sikh (2.6\%), Bazigar ( 2.3\%) and Sainsi (1.4\%). Chamar (3.5\%), Balmiki and Sainsi (.7\%) each have maximum TV, Freeze, Car, Bike and Odd (.0\%) have no these goddess. Chamar (1.6\%) have TV, Freeze, Car, Bike, Ac in maximum numbers and Kabir Panthi have .2\% minimum numbers. Ramdasiya Sikh, Balmiki, Odd, Bazigar, Sainsi, Dhanak have no these type of goddess TV, Freeze, Car, Bike, Ac. Ramdasiya Sikh, Majhabi Sikh, and Kabir Panthi have no one such these goodies in their home. The Table No. 11 shows that there is the relationship between caste and goodness. The value of $\mathrm{p}=.001$ is lower than the level of significance .005 .

\section{Conclusion:-}

In this study, All the respondents are PRI's elected members. Chamar out of nine castes have high percentage of elected members as panch (35.3\%), Sarpanch (5.4\%), Block Samities (6.3\%) and Zila Parishad(2.4\%) in PRI's. Chamar (28.8\%) have maximum respondents have from the male gender. Female respondents of Chamar, Balmiki, Ramdasiya Sikh, Bazigar, Dhanak, Majhabi Sikh are the 20.6\%, 8.9\%, 4.7\%, 2.4\% and 2.3\% each, respectively. Chamar (5.9\%), Balmiki (3.0\%), Ramdasiya Sikh (1.2\%) and Majhabi Sikh (.9\%), Bazigar, Dhanak,and Sainsi (.5\%) each are lying in age group of up to 29 years group. . In the age group of 30 to 39 years, Chamar (18.2\%), Balmiki (5.4\%), Ramdasiya Sikh (3.5\%) and Majhabi Sikh, Bazigar (2.1\%), Dhanak (1.6\%), Sainsi (1.0\%), Kabir Panthi (.9\%), Odd (.3) are admitted in it. In age group 40 to 49 years the respondents belong to the Chamar (13.5\%), Balmiki (4.4\%), Dhanak (1.9\%), Ramdasiya Sikh (1.7\%), Sainsi (1.6\%) are in maximum numbers and Kabir Panthi (.7\%) and Odd (.3\%) are in minimum numbers. Chamar (2.1\%) are highly UG passed and Odd(.3\%), Ramdasiya Sikh, Balmiki (.2\%) each are numerically low UG passed. From the Bazigar, Dhanak, Majhabi Sikh, Kabir Panthi (.0\%) have no found UG Passed. Chamar (1.4\%) are highly PG passed and .3\% Bazigar, .2\% Ramdasiya Sikh, Dhanak each are numerically PG passed. Balmiki, Majhabi Sikh, Odd, Sainsi, and Kabir Panthi (.0\%) castes have no PG classes passed. Kabir Panthi, Odd, Sainsi have no the agriculture land 2 to 4 acre. Bazigar Dhanak, Majhabi Sikh and Sainsi have no the agriculture land 4 to 6 acre. Only the Chamar (1.9\%), Kabir Panthi (.5\%), Ramdasiya Sikh (.3\%) and Balmiki, Odd (.5\%) each having agriculture land 4 to 6 acre. Bazigar, Majhabi Sikh, Odd, Sainsi have not the agriculture sect 6 to 8 acre. Chamar (1.0\%), Balmiki and Dhanak (.2\%) each having 6 to 8 acre agriculture land. Chamar (1.2\%), Majhabi Sikh and Kabir Panthi (.2\%) each having 8 to above agriculture land. Chamar (33.9\%), Balmiki (14.3\%), Ramdasiya Sikh (6.8\%), Dhanak (4.7\%), Sainsi (3.7\%), and Kabir Panthi (.9\%) have no agriculture land. The Chamar (.9\%), Balmiki (.5\%) have up to 40000rs income per year and Ramdasiya Sikh, Bazigar, Dhanak, Odd and Kabir Panthi (.0\%) each have no income such this type. The income up to 60000 have the castes Chamar (18.4\%), Balmiki (8.0\%), Ramdasiya Sikh (3.5\%) and Bazigar, Sainsi (2.3\%) each. No one have from the Caste Odd (.0\%) having income up to 60000rs. In the income group 4 lakh and above, Chamar (2.4\%) are the maximum and Dhanak, Kabir Panthi $(.0 \%)$ each have no percentage in this group. Majority of the respondents i.e. approximately 50\% were lived in Pakka house with separate toilet, bathroom and RCC roof in each castes from the selected sample. Chamar (1.6\%) have TV, Freeze, Car, Bike, Ac in maximum numbers and Kabir Panthi have .2\% minimum numbers. Ramdasiya Sikh, Balmiki, Odd, Bazigar, Sainsi, Dhanak have no these type of goddess TV, Freeze, Car, Bike, Ac. Ramdasiya Sikh, Majhabi Sikh, and Kabir Panthi have no one such these goodies in their home.

\section{References:-}

1. Sachchidananda (1977), The Harijan Elite, Thomson Press, Faridabad.

2. Ahuja Ram (2005), Society in India, Rawat Publications, New Delhi.

3. Malik, A.S. (2012), Rural leadership emerging trends, Deep and Deep Publications Pvt Ltd, New Dehli.

4. Malik, S.S. (2005), "Women empowerment and Panchayati Raj," In (ed.) Chahar S.S. Governance of Grassroots level in India, Kanishka Publishers, New Delhi.

5. Ghanshyam Shah, (edi.) (2002), Social movements and the state, Sage Publications, New Dehli. 